\title{
Synergy of corporate culture and financial control in the chaotic environment
}

\author{
Andriy Kuznetsov \\ Deptartament of Economics of Enterprises and Corporations, Ternopil National Economic University, Ternopil, Ukraine
}

\section{Email address:}

kuznetsov77@ukr.net

\section{To cite this article:}

Andriy Kuznetsov. Synergy of Corporate Culture and Financial Control in the Chaotic Environment. Journal of Finance and Accounting. Special Issue: Synergy of Accounting, Finance and Management in Chaotic Environment. Vol. 2, No. 6-1, 2014, pp. 21-30. doi: 10.11648/j.jfa.s.2014020601.14

\begin{abstract}
Organizational principles of the functional configuration of corporate culture management. The algorithm of functional configuration of the interaction and integration of financial control and corporate culture in a chaotic environment. It was proposed to identify the company's specific character with relevant determinants in 4 areas - the dynamics of the external environment, the pressure of the external environment, the business specificity and staff specific character. A road map of company's specifics research, which affects the functional organization of financial control and corporate culture management has been formed. Methodological principles defined for the election of the organizational approach (centralization, mixed and decentralization) and the combination of 5 possible functional links of corporate culture management.
\end{abstract}

Keywords: Corporate Culture, Financial Control, Synergy, Organizational Culture, Chaotic Environment

\section{Introduction}

Management effectiveness and perspectives are defined by the performance of corporate culture management. According to Cameron K. and Quinn R. [1 p.24-25] it is well known that the $3 / 4$ efforts directed on reengineering, total quality management (TQM), strategic planning and reducing the size of companies proved completely successful. Moreover, these actions are often generate problems that have determined the existence of a threat to the entire company.

The study of Kuznetsova S. proved [2] that the modern features of development of world and domestic economy, which openness, instability, dynamic and independent organization, is inherent for, stipulate the necessity of ground of new scientific approaches to forming of informative resource, priority from which is synergetic approach. Providing of the synergetic forming of informative resource foresees the complex account of different levels and forms of connections between the elements of the accounting systems as a base informative source and management on micro- and macro-levels the evolution of which strengthens their integrity and efficiency, possibility of multiple development in an unsteady economic environment taking into account statistical and dynamic laws and conformities to the law, that has determining character for becoming of "knowledge economy" in word. Considerable amount of research has confirmed that one of the fundamental reasons for this failure was the corporate culture neglecting.

The consequence of awareness of the existing situation was the development of the company's corporate culture. Wei Zheng, Baiyin Yang, Gary N. McLean investigated the results suggests that knowledge management fully mediates the impact of organizational culture on organizational effectiveness, and partially mediates the impact of organizational structure and strategy on organizational effectiveness [3]. Eccles R. G., Ioannou I., Serafeim G. investigated the effect of corporate sustainability on organizational processes and performance [4]. Elbashir, Collier, and Sutton noted, that findings showed that while top management plays a significant role in effective deployment of BI systems, their impact is indirect and a function of operational managers' absorptive capacity [5]. Linear Modeling analysis further suggests that organizational culture has more of an effect on manufacturing performance than national culture or the fit between them [6].

As a whole, the preliminary analysis of specialized literature $[10,11]$ allowed concluding that the vast majority of literature presented methodological tools aimed at assessing the corporate culture, in other words - in the final product. Thus, the issue of financial control of corporate culture 
management virtually unexplored. However, precisely this management can directly influence the corporate culture, and create, modify and maintain its profile and achieved level, position in the company and specific structuring.

Taking into account the current state of reformatting the world economy in the knowledge economy, it seems appropriate to examine and evaluate the corporate culture as an object of financial control on the one hand, and its tool that determines the economic efficiency of the companies on the other.

\section{The Methodology}

In the process of study general scientific and special methods and ways of knowing have been used. General scientific methods, including analysis, synthesis, induction, deduction, theoretical generalizations made it possible to reveal the essence of corporate culture as an object of management, identify synergies of corporate culture and financial control in the chaotic environment. Methods of observation, statistical methods to evaluate the efficiency of corporate culture management companies in Ukraine have been used. With the help of modeling techniques, analogy, statistical and graphical analysis, organizational principles of functional construction financial control management corporate culture based on specific companies have been developed.

The informational basis of research is theoretical and practical works of Ukrainian and foreign scientists on the problems of corporate culture managing; statistics; proceedings of the conference; data on practical activity of Ukrainian engineering companies that regulate corporate management; reference information and periodicals.

\section{Functional Composition of Financial Control of Corporate Culture Management Based on Specific Business}

\subsection{Algorithm of Constructing Functional Interaction and Integration of Financial Control and Corporate Culture in a Chaotic Environment}

The efficiency of corporate culture as a management tool determined by the degree of existing and company's future specific character. Despite the increased demand for Ukrainian business functional construction management of corporate culture, taking into account the companies' specific characteristics in the literature are virtually no relevant developments. The vast majority of authors $[7,8,9]$ state the need for a company to service the duties of which shall include specific management functions of corporate culture (formation, development, strategic management, change management, diagnostics, etc.) without further substantiation of theoretical, methodological and organizational principles of its construction.
During the construction of functional systems of financial control management, corporate culture must be understood to determine its place in the overall organizational structure of the company.

Algorithm for constructing functional interaction and integration of financial control and corporate culture in a chaotic environment should include:

1 Determination of the goal and functional tasks of corporate culture management (CCM) in companies;

2 Specific companies analysis that effect functional composition of financial control CCM;

3 Delineation of functional responsibilities as for decision making by the financial controller and manager;

4 Definition of the place of Financial Controller of the CCM in organizational structure of the company;

5 Definition of internal organizations of functional management of corporate culture in the company;

6 Formulation the professional and disciplinary authority and order interaction with Service financial control and service CCM in companies;

7 7. Formulation requirements to personal qualities staff service of financial control and company's CCM;

8 Development of job descriptions and divisions of Financial control and company's CCM;

9 Staff recruitment of the financial control and company's CCM;

10Training and development Staff Service financial control and service CCM.

The key areas of this definition are:

- definition of goals and functional tasks of financial control and management of corporate culture;

- specific research of the company that effect the composition of corporate culture management;

- determination of the level of the organizational structure of the company, in which the functions of financial control and corporate culture management should be performed

- identifying issues of financial control management of corporate culture which have to be integrated with other subtasks;

- formulation the authority and responsibility of decision-making on corporate culture.

\subsection{Specific Character of the Company Determination}

The starting step of corporate culture implementation is an understanding of the company since incorporation of specific features in the corporate culture management ensures its continued effectiveness and efficiency. Moreover, a variety of factors influence the company's management system determines the need for separate determinants that define specificity of functional construction of financial control and management subsystem corporate culture in different companies. Justification requires division of the fields' specification of companies, the selection of components and installation of specific determinants that define its specificity.

The analysis of scientific developments on the organization, strategy, structure and culture management companies [12, 
p.44, 13], the classification of specific features and factors of the company and the corporate culture have been conducted[5, $6,7,14]$; a preliminary assessment of Ukrainian and foreign companies and corporate culture functioning in these systems in general and interaction with the companies' environment, allowed us to separate these determinants that define functional specificity of composition management corporate culture:

1 external factors of influences that stem from the external environment of the company:

- dynamism of the environment (low; average; high);

- ambient pressure (degree; according to the nature);

2 internal factors of influence that the internal environment of the company has caused:

- specificity of business (business model; size of business; segmentation of business; organizational structure; seasonal business);

- staff specificity (responsibility; education; communication skills; level of economic thought; professional experience; own basic ideas).

Using the proposed determinants that lead to peculiarities of corporate culture within different companies will help to optimize content objectives and scope management procedures as a result of a corporate culture of their organization based on the factors of influence and will enhance overall effectiveness and adequacy of financial controls and companies' corporate culture management.

For a clear understanding of the subjects that will explore the specifics of a particular company it is necessary to formulate conditions and the impact of each of the identified determinants of functional building corporate culture management.

In order to address issues outlined circle proposes to follow the roadmap of specific research that affects its functional composition of financial control service and corporate culture subsystem management, which is shown in Fig. 1.

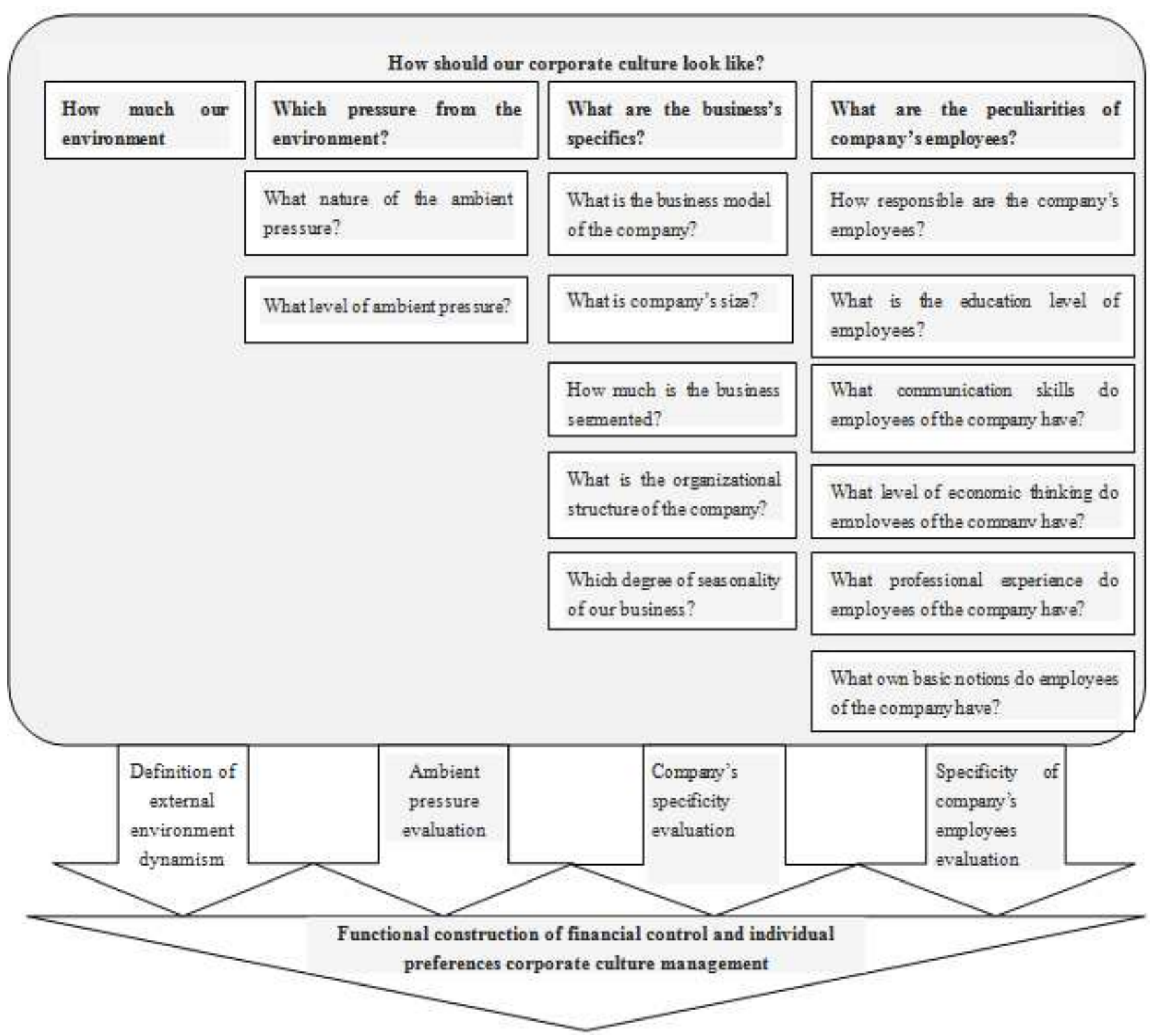

Figure 1. Roadmap research of companies'specific character that affect the functional construction of financial control and corporate culture 
It provides a phased construction of the functional management of corporate culture, which is effective for the individual preferences corporate culture formation through the study of specific companies.

The first step is to examine the specificity of the factors impact (environmental dynamism, the pressure of the environment, the local business and specific personnel).

The next step is to determine the level of environmental dynamism, assessing the nature and extent of ambient pressure on the corporate culture and the company as a whole, specific evaluation of the company's business and its staff.

Accordingly, the content and scope of the manager tasks depends on the determinants of building a corporate culture within the company.

For companies operating in conditions of stability of the environment for which are inherent, in particular, social and political stability, sustainability and supply markets (i.e. stable relationships with contractors), to control corporate culture limited to routine well-planned actions at the time as nature of the company under these conditions is constant and predictable. Thus, corporate culture management is limited by "administrator" functions.

When working in a limited degree of dynamic environmental corporate culture management should serve as a "navigator". Therefore, the service control corporate culture appropriate place additional task of checking the level of corporate culture in all business processes and tasks to develop tools to ensure quality in the form of the relevant provisions, procedures and guidelines managers.

External environment requires a high level of dynamic complex issues of company's corporate culture management, quick respond to any issues and strengthening internal control effectiveness and corporate policy and ethics adequacy. Thus, corporate culture management service acts as "innovator" and should be considered not only as an advisory body, but as a forum for the introduction in the company of a comprehensive policy corporate culture management and operational monitoring of the effectiveness of its management in the company.

One should take into account the nature and degree of ambient pressure in the company as a whole and to its staff. Such pressure may be the existence of circumstances in the external environment that promotes the distortion of corporate culture by external actors and staff at various levels of hierarchy. An example of such pressure may be the manifestation of unfair competition (including bribing personnel to destabilize corporate culture), the basic conflict of ideas corporate culture with national culture; pressure of economic and social situation in the country where the company operates.

Exploring the specificity personnel should analyze the notion of responsibility to workers for companies to determine their level of education, to assess the communication skills of employees, to determine the current level of economic thought, to assess their expertise and learn basic idea of workers from the standpoint of compliance with the basic concepts. At this stage, we have been studied the entire staff, including management.

Determining the maturity level of workers preparedness to take responsibility, determines the direction of operations management services of corporate culture in the regulation of business processes and the provisions of the corporate culture in the company. High level of percentage of workers completion to take responsibility demonstrates the achievements of appropriate sharing of staff responsibilities and the regulation of its activity, which contributes to a clear understanding of their own staff functions, powers and relationships with other employees, and, consequently, the capacity to answer for their actions.

Staff's existing educational level determines its members' ability to understand the principles and fundamentals of corporate culture and is mandatory for consideration in the preparation of recommendations for improving corporate culture, the development of internal regulations governing corporate culture in the company. Low level of workers' education requires from its corporate culture management a higher level of detailing the regulatory documents, using simple and common words and phrases by its personnel, etc. In its turn, a rather high general level of education of workers allows, in particular, using common notions without their expanded definition, building a multi-hierarchical structure of regulations, guidelines and surveys. Overall, regardless of the level of education of a certain priority is to use clear and simple forms of adaptation personnel to corporate culture.

High level of communication skills among staff promotes dynamism and adaptability in corporate culture and enables the acceleration change (reformatting) of its individual elements. Therefore, to improve staff communication is expedient to introduce considerations subcultures state test results and corporate culture in general to special meetings with representatives of all units involved in the formation of corporate culture on which verification have been carried out. It also should be mentioned that an effective discussion with employees through appropriate measures (meetings, surveys, roundtables) directions improves business processes and communication channels in the system of governance. Increasing adaptability of the basic concepts and presented the company's values can be achieved through a preliminary discussion of the draft regulations developed with service corporate culture management.

The economic way of thinking of employees affects the use of corporate culture as a tool to improve its economic performance. Thus, the presence of high levels of economic thinking makes utilitarian building a corporate culture based on pragmatism and utility (benefit) as a basic value. In general, the presence of economic thinking promotes ongoing improvement of the quality of corporate culture because employees understand the current dependence of the efficiency of decision-making and efficiency management companies on the achieved level of corporate culture. Therefore, the materiality of the determinants is effective installation tasks that would provide identification of specific 
performance corporate culture management and the introduction of incentives for workers.

The level of professional experience of employees to some extent characterizes the innovative potential of the company and determines their ability to adequately respond to changes in the corporate culture of the company, compare the quality of individual operations over time or in relation to similar operations in other groups of business processes. Taking into account existing professional experience involves posing in front of the manager specific tasks aimed at rapid detection and correction of defects in the management of corporate culture.

Learning the basic concepts of workers aims to critical assessment of their conformity basic understanding corporate culture from a position of influence, in particular, the possibility of adaptation, integration or changes. It should be appreciated that the disparities between basic beliefs of employees and corporate culture directly affect the performance of its functions on the one hand and enable impact and interchange. Therefore, functional building corporate culture management should provide monitoring of the impact and promote the equalization of corporate culture, sufficient for the company based on its business model.

When building a functional corporate culture management should take into account the specifics of its business. It is determined primarily by the current business model under which the company operates. Since the issue of forming business models are not the subject of this study will be based on the results of studies C. Zott, R. Amit [15], H. Chesbrough [16] and Ostervalder A., who pointed out that the business model describes the rationale of as an organization creates, delivers and creates economic, social or other values [17].

In general, every company building its own business model, which is formed as proved by A. Ostervalder [17, p. 16] business strategy, organization of business processes and information systems. Thus, we can say that the uniqueness of the business model determines the specific construction of corporate culture.

However, keep in mind that the world worked out certain types (templates) business models, which rely advisable to provide a unification process of building a corporate culture, as stated in previous publications approaches to information perspective of management accounting in Ukraine [10].

Building a business using a model of B2B (business to business) necessitates the formation of corporate culture aimed at stimulating the production and quality of the final product, time management (for example, the method of "just in time") and executive discipline considering permanent influence corporate cultures of others.

For companies operating within the business model B2C (business to consumer) characteristic is the broad physical interaction with end consumers in order to sell goods and services. Therefore, effective is the focus on visual artifacts, company image and enhance the impact of principles of corporate culture as dynamism, turbulence and realism.

Specificity corporate culture that operates on a business model B2G (business-to-government - business for the state) is to strengthen the defensive role, centralized management, the company's reliability as a supplier for the country's reputation in the community.

Business Model «Fermium» outlines the business organization by combining two components: provision of free goods and services to a limited version with the ability to purchase extended (enhanced, full) version. According corporate culture for companies based on this business model should facilitate innovation, intellectual property protection, quality products and services. It is important to building a reputation and visual artifacts for environmental company. When using franchising, which provides for cooperation between legally and financially independent entities (legal entities and individuals), the construction of corporate culture franchisor should consider the risks associated with the use of the trademark, know-how, trade secrets by others. Under certain priority must take the following management principles of corporate culture as alarmism, interchange, inevitable, holiness.

Size determines the volume of business procedures and information, organizational and regulatory support corporate culture. For large companies, determined to a large crowd, workers advisable to create a special functional line corporate culture management. For medium-sized companies in the vast majority is sufficient to create a separate department to manage corporate culture. Accordingly, for small companies is sufficient to include the functions of management responsibilities to the corporate culture of a top manager (CEO). At the same time, the company may be on the stage reformatting corporate culture that requires a small special unit of the companies with the establishment of additional requirements to the professional competence of experts. For large companies in this case possible combination: the creation of the Committee of the Supervisory Board on the development and implementation of control corporate culture and functional direction headed by the Director on the management of corporate culture, which is part of the management board.

Significant impact on corporate culture construction management is the current level of business segmentation. In general, segmentation (from Lat. - Segment bar) is the division of the whole into parts. In relation to business during segmentation should understand business division into separate parts with some common signs.

Generalization of scientific sources and practices of companies allowed establishing in the literature expediency separation of two lines of segmentation:

- Segmentation level (high, medium, low)

- Type of segmentation (geographic, economic).

Using economic segmentation of companies provides separation of parts of the company for the production and / or sale of a particular species (or groups) of products (goods and services). According to corporate culture, the capabilities should be based of corporate rules and regulations formation for the selected criteria separating business segments. Special attention in this context deserves the formation of the subculture segment. 
Geographical segmentation is resulting from companies' locations. This requires the use of additional levers of influence and control in managing corporate culture "at a distance". So efficient is the consolidation of the respective functions and tasks of the representatives of segments with increased monitoring central component management services corporate culture.

In general, the distribution of decision-making and specification of objectives and corporate culture management procedures depends on the segmentation of business and should be directly proportional to its growth.

The control system of corporate culture should be adapted to the organizational structure of the company. Therefore, functional building corporate culture management must take into account the peculiarities of the organizational structure of the company. It is the specificity of the common organization of the hierarchy and determine the nature of the interaction between the business units.

Linear organizational structure characterized by restriction levels of functional management. Therefore, the functional building corporate culture management should be based on the level of financial and human resources of the company, the capacity of the existing corporate culture to perform its functions and competence of officials, which can put a duty control corporate culture.

Linear-functional organizational structure determines the feasibility of a separate directly control corporate culture. This allocation of duties between employees should be organized on the basis of their subordination.

Divisional organizational structure requires appropriate detail the functions of corporate culture management within the specified offices of the company. It is therefore advisable to organize service corporate culture management (or subculture) for each department, who act as independent centers of individual responsibility.

The matrix of organizational structure presents an organization that is built on the principle of double subordination performers on the one hand - functional service supervisor, on the other - the head unit (project target program), which has the power to control in accordance with the planned timing, resources and quality. Therefore, functional construction of corporate culture management should include a separate service at the company level and securing responsible for managing the corporate culture within the business units.

Seasonality is inherent to the business of agriculture, hunting and forestry; lesser extent - for construction, hotels and restaurants, trade, cultural activities and sports; little impact - for education, for the real estate operations, leasing. Seasonality requires strengthening the stability of the corporate culture of the company due to lack of specific activity during the period. This requires determining the volume of corporate culture management procedures depending on the season.

Special attention is given definition of functional internal control corporate culture in the company. Considering the functional construction management corporate culture, it is necessary to provide for the establishment of corporate culture management system (which is a subsystem of management companies) regardless of the specific characteristics inherent in a particular company. Thus, it is crucial specifics of formation parameter model organizational structure of the corporate culture at the company.

Functional construction corporate culture management is defined by the chosen approach to their organization:

1) centralization - provides for the creation of separate departments for managing corporate culture;

2) decentralization - provides distribution management functions among of existing corporate culture officials and structural departments

3) mixed - provides for the establishment of a separate line for managing corporate culture, followed by detailed management functions corporate culture among of existing departments.

Specifying approach for each company depends on the particular purpose and functional problems faced by management corporate culture.

Possible levels of functional control corporate culture are systematized in Fig. 2.

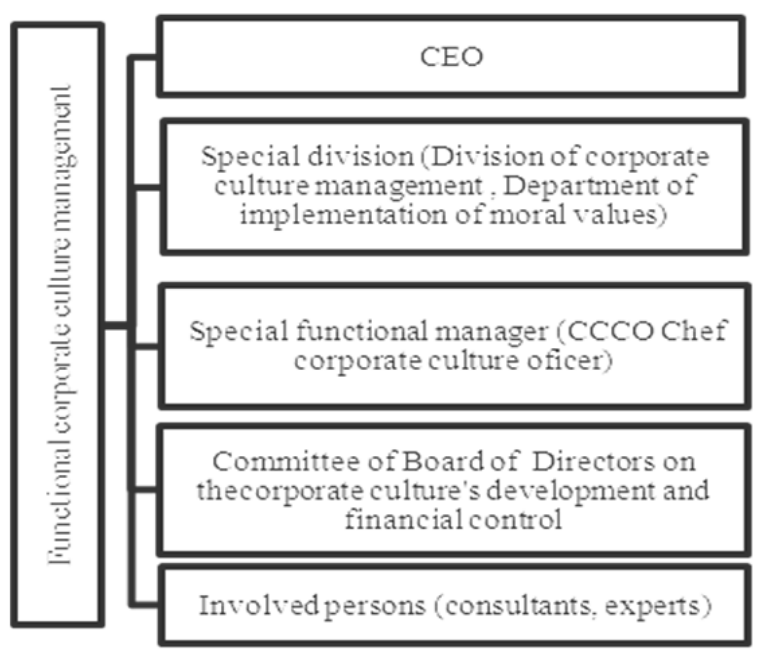

Figure 2. Links of functional corporate culture management in the company

With the formation of individual functional model building corporate culture management of each company based on its specificity may use different combinations of defined units.

So, while reformatting a great corporate culture of the company, which has a high level of business segmentation along with the essential difference of their own basic ideas of staff and corporate culture and operating in a dynamic environment it is advisable to build such a structure: Committee of the Supervisory Board for the development and monitoring of implementation of corporate culture, the Special functional direction headed by the Director to manage corporate culture and Employment of Consultants alignment with basic ideas and values. In turn, etc. For a small company, which has a low level segmentation and slight pressure of the environment and works with B2C business model effectively put corporate culture management responsibilities to the CEO. 


\section{Corporate Culture Efficiency Analysis of Ukrainian Companies}

The analysis of the main indicators of Ukrainian engineer, whose results are presented in Table 1 and summarized in Fig. 3-6 indicates overall negative trend for the conservation of a range of unprofitable engineering companies within $33.9 \%$ $-39.9 \%$.

Table 1. Earnings before taxes of Ukrainian engineering companies (formed on the basis of the author [19, 20])

\begin{tabular}{|c|c|c|c|c|c|}
\hline & \multirow{2}{*}{$\begin{array}{l}\text { EBT } \\
\text { mln UAH. }\end{array}$} & \multicolumn{2}{|c|}{ Profitable companies } & \multicolumn{2}{|c|}{ Loss-making companies } \\
\hline & & $\%$ of total & $E B T, m \ln . U A H$. & $\%$ of total & $E B T, m \ln . U A H$. \\
\hline 2012 & 13610.5 & 66.1 & 16311.1 & 33.9 & $(2700.6)$ \\
\hline large companies & 9098.1 & 82.0 & 9717.0 & 18.0 & $(618.9$ \\
\hline average companies & 4331.3 & 68.2 & 5958.8 & 31.8 & $(1627.5$ \\
\hline small companies & 181.1 & 65.3 & 635.3 & 34.7 & $(454.2$ \\
\hline 2011 & 14637.6 & 67.3 & 1703.6 & 32.7 & $(2416.0$ \\
\hline large companies & 9508.5 & 89.7 & 10219.6 & 10.3 & 711.1 \\
\hline small companies & 256,7 & 66.5 & 629.9 & 33.5 & 373.2 \\
\hline 2010 & 6859.0 & 60.2 & 9771.5 & 39.8 & 2912.5 \\
\hline large companies & 4891.9 & 73.6 & 6139.5 & 26.4 & 1247.6 \\
\hline middle companies & 1874.3 & 60.6 & 3230.4 & 39.4 & 1356.1 \\
\hline small companies & 92.8 & 59.9 & 401.6 & 40.1 & 308.8 \\
\hline 2009 & 1974.8 & 60.7 & 8359.7 & 39.3 & 6384.9 \\
\hline
\end{tabular}

Comparing the growth in financial results before tax and dynamics of working time for engineering companies of Ukraine (which shows the fall and ranges from 0,71-0,84) allows to state that a possible source of income is the preservation of the price factor, confirmed by official statistics.

Studying the situation of employment of engineering companies of Ukraine confirms the general trend during the period 2007-2012.

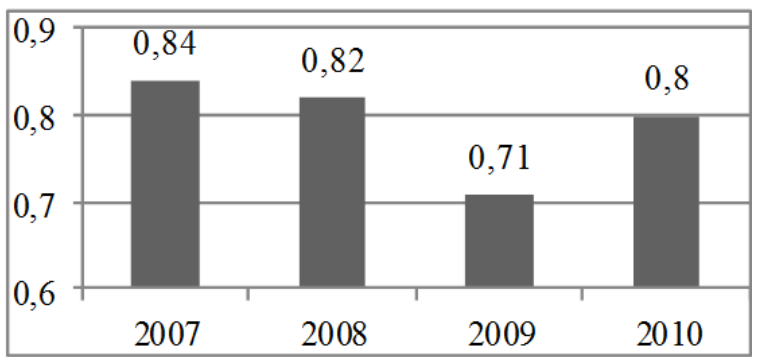

Figure 3. Dynamics of working time for engineering companies of Ukraine (formed on the basis of the author [19,20])

Research indicators of financial results, detailed size engineering companies allowed to conclude that the largest share of profits in absolute terms is in great company: $71.3 \%$ in $2010,65 \%$ - in 2011., 66.8\% - in 2012. However, the fate of large profitable companies is unstable: $73.6 \%$ in 2010 . , $89.7 \%$ in 2011 , and $82 \%$ in 2012. This trend of gradual increase in the proportion of profitable small companies: $59.9 \%$ in 2010 , $66.5 \%$ in 2011, and, respectively, $65.3 \%$ - in 2012.

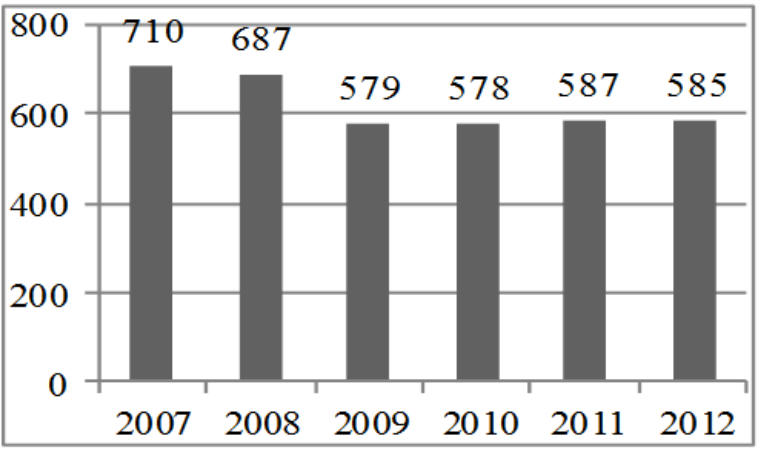

Figure 4. The annual average number of employees at engineering companies of Ukraine, thous. people (formed on the basis of the author [20,21])

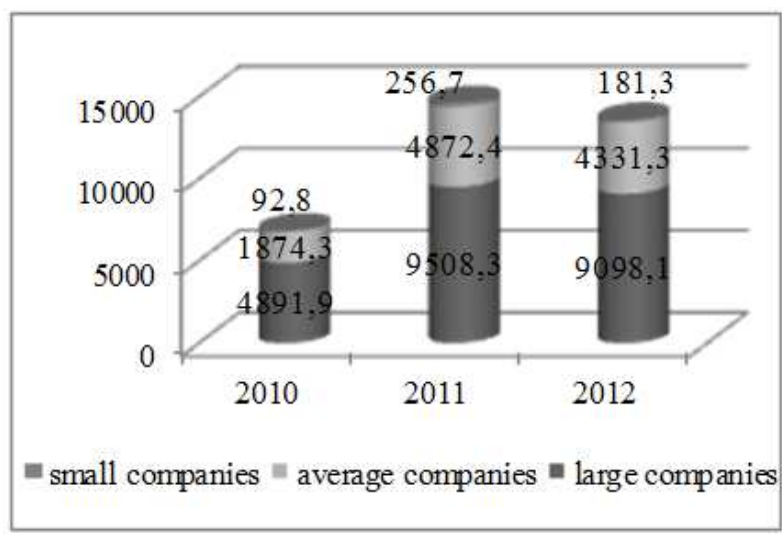

Figure 5. Dynamics of profit before tax in Ukrainian engineering companies, mln. UAH. (formed by the author on the basis of sources [19,20,21]) 


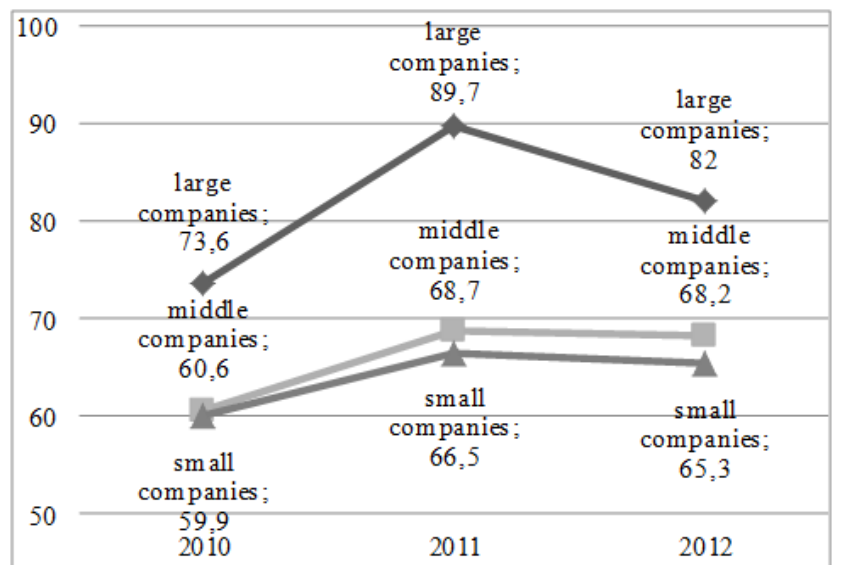

Figure 6. Dynamics engineering companies of Ukraine who received income\% (formed by the author on the basis of sources $[19,20,21]$ )

As the results show, the priority of Ukrainian engineering is to preserve profits and efficiency of work, along with a gradual decrease in the average number of employees. In this area it is typical of reformatting to increase share of profitable small companies along with the unstable situation for large companies.

The outlined situation justifies further comprehensive assessment of corporate culture management companies based on their own specific as a powerful tool for economic and social growth.

General condition corporate culture management of Ukrainian companies has been analyzed. It has been investigated the efficiency of corporate culture management functions for 11 companies. The selection was made on the basis of representation of different types of companies for specific production (including - production of motor vehicles, construction vehicles in floating structures, engineering cooling and ventilation equipment Manufacture of machinery and equipment for agriculture and forestry, manufacturing tools) and size (large, medium and small companies).

An issues list and content management function is to some extent controversial nature in the literature. Therefore, studying the functions of corporate culture management has been considered the most common approaches to reduce the risk of inaccurate interpretation of the essence of each of the respondents and features more objective results. Overall analysis of the following functions implementation: planning, organization, implementation (instruction), control, motivation and regulation.

Although it appeared to be axiomatic that the primary function of management is planning companies in the first place was the implementation function. This situation is explained by two factors. First low is awareness of the value of corporate culture management as a management tool. Second, challenging, and sometimes crisis in Ukraine companies that causes accentuation account managers on finding financial capacity of its stabilization work with potential investors and creditors.

Function is performed by implementing existing programs without corporate culture (e.g., programs combining moral values to specific actions to improve performance).

Organizational function reduces to the development of norms and rules that govern relationships with employees and the development and dissemination of visible artifacts. In the company there are no special units and workers, who are directly responsible for implementing the company's values. Coordination function is realized by $27 \%$ of surveyed companies through general meetings and business correspondence.

Given the results of the research corporate culture management does not perform the functions of planning. The control function in this process forms the basic framework for target accumulation of the necessary information on the effectiveness of corporate culture, which is subject to further analysis and is the basis for making corrective action. However, 6 studies of companies that implement this function, it appears within the control of financial performance and partly social and employment indicators are calculated in the preparation of statistical reports. Despite the fact that $45 \%$ of respondents confirmed the implementation of the tool to motivate, to Ukrainian companies surveyed no special cultural program staff. The control functions used in part, in most cases in the settlement of labor disputes and conflicts.

Effectiveness of corporate culture is defined by the quality of its software.

Information support is formed within the general information needs of managers and is used selectively in making operational and tactical management decisions. Financing corporate culture management is carried out within the costs of incentives for workers (including premiums, annual payments, social package), the cost of corporate activities and the cost of the artifacts (the largest share: the cost of corporate attributes and corporate identity).

This proves the fact that the corporate culture is not seen as a complete object management, corporate culture in companies carried out haphazardly, in most cases within general management and operational issues that arise, is available active effective management mechanism.

\section{Conclusions}

The efficiency of the corporate culture as an object of financial control on the one hand, and its tool that determines the cost-effectiveness of the companies on the other, determined by the degree of adequacy of existing and future company specifics. During functional integrated construction of the financial control and corporate culture should be understood the definition of their place in the overall organizational structure. The key steps of this composition are: determining the purpose and function of management tasks; specific research company that affects the functional composition; outlining the level of organizational structure which would focus and management functions by performed corporate culture; identifying issues of corporate culture management that will integrate with other sub-tasks; formulation the powers and responsibilities of management decisions on the corporate culture of the company. 
Determinants that define functional specificity while corporate culture and financial control formation in a chaotic environment are: dynamism and ambient pressure; specific business and staff.

Functional construction of corporate culture and financial control should be developed using the roadmap and local business, which it is reasonable to estimate for 5 subjects (business model (B2B, B2C, B2G, «Fermium», franchising), the business size, the business segmentation (for view (geographic, the Economic) and level (high, medium, low), organizational structure, business seasonality).

Allocation of authorities and specification of objectives and procedures for financial control and corporate culture depends on the business segmentation and should be directly proportional to its growth. The control system of corporate culture should be adapted to the organizational structure, which determines the specificity hierarchy and nature of the interaction between departments and divisions. Seasonality of business needs to determine the volume of corporate culture management procedures depending on the season.

Approaches to the corporate culture management are centralization, decentralization, mixed. It is necessary to provide for the creation of management is corporate culture (which is a subsystem of enterprise management system), regardless of the specific characteristics inherent in a particular company. Thus, it is crucial specifics company formation parameter model organizational structure of the corporate culture at a particular facility.

The links of functional corporate culture management in the company may be the Head of the company, the Special Department (Department of corporate culture management, Department of introducing moral values), Special functional direction (management director of corporate culture), the Committee of the Supervisory Board on the development and implementation of control corporate culture involved persons (consultants, experts). With the formation of individual functional model, building financial control and corporate culture for each company based on its specificity may use different combinations of defined units.

This allows forming some individual preferences models of functional management and effective financial control over the corporate culture with a specific company.

\section{References}

[1] Kim S. Cameron, Robert E. Quinn, Diagnosing and changing organizational culture: based on the competing values framework, Wiley, 2011.

[2] S. Kuznetsova, "The transformation of accounting systems in the chaotic economy structuring: the synergetic approach, Risk and Decision Analysis”, Vol.3, 2011, pp. 151-160.

[3] Wei Zheng , Baiyin Yang , Gary N. McLean . "Linking Organizational Culture, Structure, Strategy, and Organizational Effectiveness: Mediating Role of Knowledge Management. Journal of Business Research Volume 63, Issue 7 , July 2010, p. 763-771.
[4] Eccles Robert G., Ioannou Ioannis, Serafeim George. "The impact of corporate sustainability on organizational processes and performance", Working Paper 17950. http://www.nber.org/papers/w17950

[5] Mohamed Z. Elbashir, Philip A. Collier, and Steve G. Sutton , "The Role of Organizational Absorptive Capacity in Strategic Use of Business Intelligence to Support Integrated Management Control Systems". The Accounting Review: January 2011, Vol. 86, No. 1, p. 155-184.

[6] Michael Naor , Kevin Linderman , Roger Schroeder " "The globalization of Operations in Eastern and Western Countries: Unpacking The Relationship Between National and Organizational Culture and Impact on manufacturing ITS Performance", Journal of Operations Management Volume 28, Issue 3 , May 2010, p. 194-205.

[7] Levin IM, Gottieb J. "Realigning organization culture for optimal performance: six principles \& eight practices", Organization development journal. 2009, no4, pp. 31-47.

[8] Kilmann, RH, Saxton MJ, R. Serpa "Issues in Understanding“, California Management Review. 1986, vol. 28, pp. 87-94.

[9] Jaffe P. Organization Theory: tension and change. Mc Grawhill International Editions, New York, 1996.

[10] Kuznetsova S., Kuznetsov A. "The information perspective of management accounting in Ukraine: the synergistic approach and Arrow's impossibility theorem", World Journal of Social Sciences. Zia World Press, Australia. Vol. 4. No. 1. March. 2014. pp. $140-153$.

[11] Kuznetsova S., Kuznetsov A. "Formation of corporate culture based on the specifics of the company", Problems of economy, 2011, vol.4, pp.91-94.

[12] Bleicher, K. Organisation, Strategien, Strukturen, Kulturen, Aulf. Wiesbaden, 1991.

[13] Mohan ML Organizational communication and cultural vision. Albany, State University of New York Press, 1993.

[14] Schein, Edgar H. The corporate culture survival guide, John Wiley \& Sons, 2009.

[15] C. Zott, Amit R. Exploring the Fit between Business Strategy and Business Model: Implications for Firm Performance [electronic resource]. - Mode of access: http://wwwmanagement.wharton.upenn.edu/amitresearch/docs /9_07/Amit_Zott_Business_Strategy_Fit_2006.pdf.

[16] Chesbrough H. Rosenbloom RS, "The role of business model in capturing value from innovation: evidence from Xerox Corporation's technology spinoff companies", Industrial and Corporate Change, 2002 , pp. 529-555.

[17] Osterwalder, A. How to describe and improve your Business Model to Compete Better, Treatment [electronic resource]. Mode of access: $\mathrm{http} / /$ www.privatebankinginnovation.com/en/wpcontent/uplo ads/tools/DraftBusinessModelManual.pdf.

[18] Osterwalder A. The Business Model Ontology. A proposition in a design science approach, 2004 - Access: http://www.hec.unil.ch/aosterwa/PhD/Osterwalder_PhD_BM Ontology.pdf

[19] State Statistics Committee of Ukraine Access to materials: http: II www.ukrstat.gov.ua 
[20] Statistical Yearbook "Industry of Ukraine" in 2007-2010, Kyiv / State Statistics Service of Ukraine, 2011.
[21] Statistical Yearbook "Industry of Ukraine" "Labor Ukraine 2012" - K .: State Statistics Service of Ukraine, 2013. 